\title{
Indo-Europeanization - the seven dimensions in the study of a never-ending process
}

\author{
Harald Haarmann \\ Institute of Archaeomythology (Sebastopol, USA), European Branch \\ harald.haarmann@pp.inet.fi
}

\begin{abstract}
This contribution focuses on the multifaceted process of Indo-Europeanization which started out, in the Pontic-Caspian region, with the formation of a distinct ethno-cultural epicenter, the Proto-Indo-European complex. Since the late Neolithic, the Indo-Europeanization of Europe and parts of Asia produced various scenarios of contact and conflict. Altogether seven dimensions are highlighted as essential for the study of the contacts which unfolded between Indo-Europeans and non-Indo-European populations (i.e., Uralians, Caucasians, ancient populations in southern and central Europe). Selective aspects of cultural and linguistic fusion processes during the Neolithic and subsequent periods are discussed, and the controversial term 'migration' is redefined.
\end{abstract}

IZVLEČEK - Ta prispevek se osredotoča na večfasetni proces indoevropeizacije, $k$ i se je začela na Pontsko-kaspijskem območju z oblikovanjem izrazitega etno-kulturnega epicentra, proto-indo-evropskega kompleksa. Od mlajšega neolitika dalje je indoevropeizacija Evrope in delov Azije proizvedla različne scenarije kontakta in konflikta. Predstavljenih je sedem bistvenih dimenzij, pomembnih za preučevanje kontaktov, ki so so potekali med Indoevropskimi in ne-Indoevropskimi populacijami (Ural, Kavkaz, stare populacije v Južni in Srednji Evropi). Razpravljamo o selektivnih aspektih procesov kulturnega in lingvističnega zlitja v času neolitika ter kasneje. Ponovno smo opredelili kontroverzni pojem "migracija».

KEY WORDS - formation of ethnic stocks; transition to pastoralism; early language contacts; movement from the steppe zone to the west; cultural fusion and linguistic convergence

\section{Introduction: A Complex Agenda}

The history of Europe's peoples, cultures and languages is the history of Indo-Europeanization. This process started somewhere, some time, and it is still unfolding. In fact, the Indo-Europeanization of Europe and other regions of the world will not come to an end as long as there are non-Indo-European languages and cultures that withstand the pressure of constant assimilation and acculturation.

As for Europe, the great majority of its recent populations speak Indo-European languages. Until the Neolithic, the proportions of non-Indo-European and Indo-European languages in Europe were the opposite of modern times, with Palaeo-European languages of non-Indo-European affiliation dominating the linguistic landscape (Haarmann 2002).
In Western Europe, Basque in southwestern France and northern Spain is the only surviving non-IndoEuropean language from antiquity (Haarmann 1998a). The Basque community has suffered a continual loss of its area of distribution and of the number of speakers of Basque since the tenth century $\mathrm{AD}$, under the pressure of Spanish and French.

In central Europe, Hungarian (of Finno-Ugric affiliation within the Uralic language family) is like a nonIndo-European island amidst Indo-European speech communities. Northeastern Europe is home to a number of Finno-Ugric languages. Of these, Finnish, Estonian and Saami are the best known. Among the Finno-Ugric minority languages in the European part of Russia, processes of assimilation to the Russian-spea- 
king environment have caused a decline in the number of speakers of languages such as Mordvin, Mari, Udmurt, Komi and others (Abondolo 1998).

In the Pontic-Caspian region (that is, in the area between the Volga in the west, the Caucasus in the south and the Ural mountains in the north), several languages of Turkic affiliation (as a branch of the Altajic language family) are spoken, among them Tatar (Kazan Tatar), Chuvash, Bashkir, Nogay, Kumyk, Karachay-Balkar and others. The presence of Turkic speech communities in that region is due to the migrations of Turkic tribes during the Middle Ages (Menges 1995.19-23). Many of the early migrant communities such as the Huns, Avars, Khazars, Volga Bolgars, Pechenegs, Onogurs and others that had established themselves in the steppe zone and adjacent areas have vanished from the ethnographic landscape.

The speech communities of the minorities in the eastern areas of the European part of Russia, of FinnoUgric and Turkic affiliation, have experienced a weakening of the social functions of their languages and, in some regions, the younger generation has no more command of the mother tongue, which has been lost to Russian (Haarmann and Holman 1997; 2000).

In order to understand the magnitude of the IndoEuropeanization process in the horizon of time it is significant to shed light on its dynamic history. The beginnings of that dynamic process are associated with the circum-Pontic region and date to the Neolithic. The story of human populations, their cultures and languages in the area north of the Black Sea is a fascinating sequence of early sustainability, internal change and subsequent external expansion. The basic processes of human ecology can be observed in the span of time from the immediate post-glacial period to the Late Neolithic. In the course of time, the pace of cultural development accelerates to culminate in the dynamic fragmentation of the Proto-IndoEuropean complex. During this crucial stage, which covers the period between $c .4500$ and $c .3000 \mathrm{BC}$, the process of Indo-Europeanization is set in motion.

This process has been described as a replacement of the ancient languages of Europe by the imported Indo-European languages (Renfrew 2002b.6-7). The idea of replacement readily associates situations of daily life when older equipment (e.g., a car, a TV set or a computer) is literally re-placed by a new machine. Such a notion of replacement is far from rea- listic and even misleading in this context of culture studies (Haarmann 2007.ch. 5.3).

Ancient populations, cultures and languages do not simply vanish. They always leave traces. This is true for the non-Indo-European peoples and their cultures in Europe and Asia that came in contact with and under pressure from Indo-Europeans. The Indo-European cultures and languages that spread did not replace the local languages of different linguistic affiliation. They entered into a process of fusion with them, so as to produce various locally specific patterns of a cultural-linguistic blend of old and new constituents.

In this contribution, new perspectives for pinpointing the beginnings of the process of Indo-Europeanization, the area of its irradiation and its dynamic unfolding are explored. The study of this agenda is of great complexity and requires the investigation of altogether seven dimensions:

- the economic dimension (e.g., the question of the transition from foraging to pastoralist subsistence), - the sociopolitical dimension (e.g., the emergence of stratified society and statehood in southeastern Europe),

- the ethnic dimension (e.g., configurations of genomic profiles of local populations in areas that were Indo-Europeanized),

- the cultural dimension (e.g., fusions of divergent cultural traditions among populations in contact, such as the Mycenaean-Minoan or Celtiberian symbioses),

- the linguistic dimension (e.g., patternings of indigenous and borrowed elements in lexical structures and word formation; shifts in word order),

- the visual-artistic dimension (e.g., the spread of diagnostic imagery related to the horse, such as horse-headed sceptres in the steppe zone, and figurines depicting the horse goddess as in the Celtic tradition),

- the mythical dimension (e.g., the role and functions of pre-Greek goddesses such as Demeter, Hestia, Athena and others in Greek mythology).

In the present contribution, argumentation for a selection of these dimensions is presented.

\section{The identification of the Indo-European home- land}

The agenda of Indo-Europeanization is intrinsically interwoven with the issue of the origins of Indo-Eu- 
ropeans, their cultures and languages. Any assessment of the movements of Indo-European populations depends on the geographical identification of the homeland. The debate about the Indo-European homeland has a history of over 150 years. Some ten homeland candidates have been seriously discussed since the twentieth century. Of these, two are still a matter of lively debate. The two major hypotheses stand in sharp contradiction with each other:

Alternative 1 The early Indo-Europeans were agriculturalists and migrated from their original homeland in western Asia (Anatolia) to the west (southeastern Europe) and to the east (Iranian plateau, India).

Alternative 2 The early Indo-Europeans were pastoralists and migrated from their original homeland in eastern Europe (the area north of the Black Sea) to the west (to southeastern and central Europe) and to the east (into central Asia and beyond).

The issue of the Indo-European homeland is extremely complex. It is not possible to identify the homeland with any certainty while applying the methodology of one single scientific discipline only. Inquiries into the homeland agenda have been made by historical linguists, anthropologists, archaeologists, ethnographers, geneticists, historians of religion and culture, and they all have contributed to our knowledge of the prehistoric conditions of the spread of IndoEuropean populations, cultures and languages.

The Pros and Cons of the modern debate have been mapped out in a recent study (Haarmann 2006 . 152-170). The author of the present contribution takes a stand for Alternative 2 as the original homeland of Indo-Europeans. Some of the major arguments in favour of the northern Pontic zone as a homeland will be summarized in the following. Besides arguments for a positive identification, the analysis will also take into consideration aspects of a negative identification, that is, arguments of exclusion. One of these exclusive argumentations is the evidence that the original population in southeastern Europe was of non-Indo-European stock, thus excluding the validity of this region as a possible candidate for an extended homeland.

The genetic map for southeastern Europe and western Asia shows a pattern which has been identified as the 'Mediterranean genotype' (Map 1). This is a so-called local genetic 'outlier' because it differs markedly from surrounding patterns.
In their archaeological and cultural interpretation of genotypes, Cavalli-Sforza and his colleagues relate the Mediterranean genotype to the geographical dispersal of the Greek population during the times of colonization in the eastern Mediterranean, that is, to the period of the early first millennium BC (CavalliSforza et al. 1994.290-296; recently repeated in $\mathrm{Ca}$ valli-Sforza 2000.119-120). However, upon closer inspection of the geographical profile of this genetic outlier, it becomes apparent that the contours of the Mediterranean genotype do not coincide with the historical boundaries of the Greek population.

The area covered by the inner genetic gradient of the genotype expands far beyond the gravitational limits of Greek settlements. Greeks never settled in regions situated nowadays in Bulgaria, Romania, Serbia, Albania or Bosnia-Hercegovina. They did not settle as far as central Anatolia either, where the inner gradient extends to the east. Even in the western part of Anatolia, on the eastern coast of the Aegean Sea, the Greek population concentrated in urban centers and only very scarcely settled in rural areas. A sizeable population, however, must have shaped the genetic profile of the region.

When inspecting the distribution of the second gradient of the genetic outlier, the assumed association of the Mediterranean genotype with Greek settlement becomes even more improbable. Furthermore, the question has to be asked: why would the Greek genotype differ so radically from the genetic profiles of the neighbouring Indo-European populations if not for the reason that it reflects a substantial substratum in the region of divergent ethnic stock? A comparison with the profile of other principal components shows that the gradients which cover the

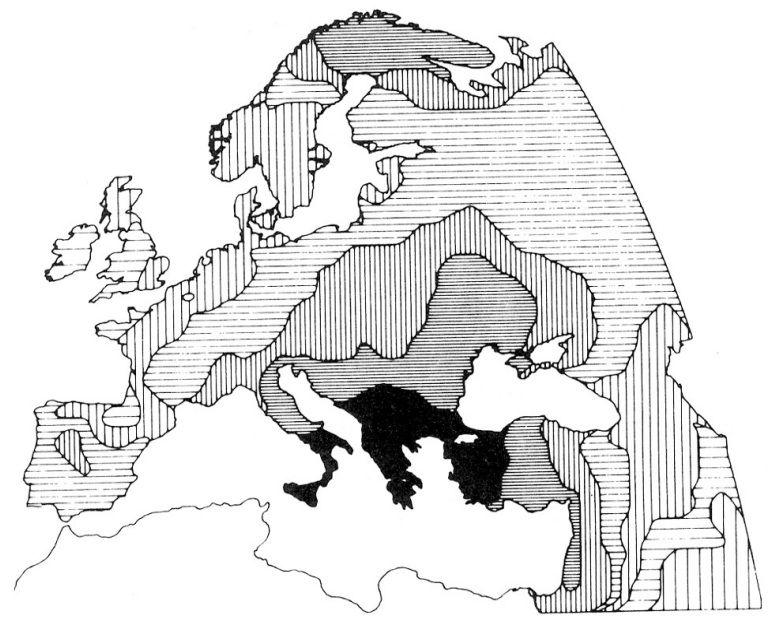

Map 1. The Mediterranean genotype (after CavalliSforza 1996.63). 
southern Pontic zone, respectively, form a consistent belt stretching on either side of the Bosphorus, without any significant profile of the Greek stock having been made.

There is a more plausible explanation for the geographical extension of this genotype, and this is that it reflects the stratum of the pre-Greek population. In all probability, the Mediterranean genotype documents the density of non-Indo-European settlements in the circum-Pontic region. In an anthropological perspective it becomes apparent that the population around the Aegean Sea stretching on the European and on the Asian side of the southern Pontic zone was ethnically homogeneous, which does not exclude the possibility of cultural and/or linguistic diversity.

There is the question of time depth. When did nonIndo-Europeans live in the circum-Pontic region? Given the possibilities of free movement between Asia and Europe in the pre-deluge era (that is, before $c$. $6700 \mathrm{BC}$ ), it can be conjectured that demographic diffusion happened long before $7000 \mathrm{BC}$. The nonIndo-European population of the circum-Pontic region reflects the continuous presence of foragers who had roamed the wood- and grasslands of western Asia and southeastern Europe since the Mesolithic Age. There is clear evidence for the continuity of populations in the region from the Upper Palaeolithic onwards (Bailey 2000.16-38). In the light of this assumption of a very old circum-Pontic population of non-Indo-European stock, the spread of agriculture in southeastern Europe is understood as being due primarily to idea diffusion rather than the migration of agrarian settlers from Anatolia to Europe (Haarmann 1998b; Budja 2001.29-31).

The data provided by human genetics do not unilaterally favour the idea of demic diffusion from western Asia into Europe. There is no genetic evidence for one big wave of population transfer during the seventh millennium BC. On the contrary, recent research confirms the view that, in southeastern Europe, the process of Neolithization is characterized by several small-scale movements of populations within geographically limited ranges (Semino et al. 2004; Di Giacomo et al. 2004).

The non-Indo-European population of the circumPontic region not only left a genetic 'footprint', but also linguistic traces of their presence. These traces are best preserved by toponymy and hydronomy. The non-Indo-European elements that can be iden- tified in the names of places, rivers and phenomena of the natural environment form part of the most ancient onomastic residue. Characteristic of the onomastic roots of non-Indo-European origin are certain suffixes (i.e., -ss-, -nd-, -nth-). The formative element $-s s$ - is the most frequent in this group of names: Assa (Macedonia), Bubassos (Caria), Passa (Thrace), Sardessos (Troad), Termessos (Pisidia), Kabassos (Lycia), Larissa (Thessaly), etc. (Otkupshchikov 1973. 7-9, 20-23).

Certain onomastic roots occur in names on either side of the Aegean:

$\begin{array}{ll}\text { European side } & \text { Asian side } \\ \text { Alos (Thessaly) } & \text { Alinda (Caria) } \\ \text { Bargos (Illyria) } & \text { Bargasa (Caria) } \\ \text { Kurba (Crete) } & \text { Kurbasa (Caria) } \\ \text { Leba (Macedonia) } & \text { Lebinthos (Caria) } \\ \text { Oinoe (Attica) } & \text { Oinoanda (Lycia) } \\ \text { Passa (Thrace) } & \text { Passanda (Caria) } \\ \text { Prinos (Argolid) } & \text { Prinassos (Caria) } \\ \text { Sardos (Illyria) } & \text { Sardessos (Troad) } \\ \text { Sindos (Macedonia) } & \text { Sinda (Pisidia) } \\ \text { Tegea (Arcadia) } & \text { Tegessos (Cyprus) }\end{array}$

In an onomastic survey of the circum-Pontic region, the distribution of names containing these formative elements points to a balanced dispersal in Europe and Asia. In the Aegean Archipelago and in the Balkans we find altogether 181 names, in contrast to 175 names in Asia Minor. The highest concentration of these pre-Greek names can be observed in the historical areas of Caria, Crete, Thrace, Thessaly, Macedonia and Troy. The onomastic material of preGreek origin is most verified on the islands and in the coastal areas of the Aegean Sea: e.g., Arakynthos (names of mountains in Aetolia, Boeotia and Attica), Tiryns (gen. Tirynthos, town in Argolis), Titaresios (river in Thessaly), Ordymnos (mountain on Lesbos), Mykonos (island in the Cyclades), Kameiros (city on Rhodes), Skiathos (island in the Cyclades) (Katičić 1976.42-55).

The assumption of a pre-agrarian population of nonIndo-European stock in the circum-Pontic region stands in sharp contrast to the hypothesis of a presumed old Indo-European population in the area. This hypothesis which was first publicized by Colin Renfrew (1987) and adopted by Luca Cavalli-Sforza and others relates the spread of agriculture to early Indo-European migrations from western Asia to southeastern Europe. According to Renfrew these migrations were large-scale and included a great number of people. If the spread of agriculture was 
related to possible migrations, this population movement must have taken place in the course of the seventh millennium BC. However, the argumentation in favour of an old Indo-European population in southeastern Europe (see Renfrew 1999 for a remake of his earlier claims) fails to give convincing answers to crucial questions (see a-d below) concerning the antiquity of Anatolian languages.

The hypothesis that Indo-Europeans were the autochthonous population of Anatolia brings up the question of who were the bearers of the high culture at Çatalhöyük? Since this culture started to flourish as early as $c .7250 \mathrm{BC}$, it would be hazardous to associate it with cultural activities of proto-Indo-Europeans. Even if the Indo-European homeland is sought in Anatolia, there would be many difficulties to link Çatalhöyük with Indo-Europeans. The assumption of an Anatolian homeland places this "within eastern Anatolia, the southern Caucasus, and northern Mesopotamia" (Gamkrelidze and Ivanov 1995.791). This means, if Indo-Europeans had anything to do with Çatalhöyük, they would have had to migrate first from their homeland to western Anatolia long before $7000 \mathrm{BC}$, and there is no evidence whatsoever for such an early migration. It seems much more reasonable to suppose "Catal Hüyük was part of a different, non Indo-European, culture" (Duhoux 1998.31).

In addition to the arguments that have been brought forward in connection with the evaluation of the Mediterranean genotype which contradict the assumption of an old Indo-European population in the circum-Pontic region, there is further circumstantial evidence for the absence of Indo-Europeans and for the presence of non-Indo-Europeans there. Several issues will be addressed here briefly.

a. Were the Proto-Indo-Europeans sea-faring? The answer to this question is negative. In the lexical layers of the protolanguage as far as it can be reconstructed there is no old vocabulary relating to seafaring. The lexical items which are associated with water in a natural environment refer to lakes, riverine landscapes, marshes and swamps, but not to the sea. It is significant that the Greek term for sea, thalass $a$, is of pre-Greek (non-Indo-European) origin. Since the flood of $c .6700 \mathrm{BC}$ destroyed the land bridge and separated Europe from Asia (see Haarmann $2006 \mathrm{~b}$ for an outline of the consequences of that event), sea-faring must be assumed as a precondition for the migrations that allegedly took place in the post-deluge period. If there had been migrations requiring sea-faring at that early period, then the people involved were definitely not Indo-European speakers.

b. Were Indo-European immigrants responsible for the promotion of sedentary life-styles on the European side of the circum-Pontic region? In recent years, more and more attention has been paid to the nature of processes of acculturation that might well have been responsible for foragers to accustom themselves to a sedentary life-style. According to the acculturation hypothesis (see Whittle 1996.4346 for this terminology), the diffusion of the idea of food production in combination with lively trade provided the incentive for foragers to adopt farming. In connection with the spread and regional appearance of seals in the archaeological assemblages, it has been stated that

"... they may indicate more structured and intensive patterns of social networks and the circulation of goods and people over short, medium and long-distances in the Eastern Balkans, the Peloponnese and Anatolia which followed the structural trajectories of hunter-gatherers into farmers." (Budja 2005.66).

To explain the transition to plant cultivation among the populations in the Balkan region, the hypothesis of an immigration of farmers is not needed. Evidently, there is a growing tendency among archaeologists to favour the acculturation hypothesis. In a number of scholarly contributions, the assumption of a possible interconnection between Indo-European migrations and the spread of farming has been discarded (see Haarmann 1998b and Dergachev 2002 for basic arguments). The crucial question of how long the transition from foraging to farming (that is, the acculturation process) might have lasted has still to be investigated with more scrutiny. It might have lasted longer in some areas than in others. The Baltic region provides well studied settings where the transition to farming lasted several hundreds of years and was associated with lively trade contacts and inter-ethnic social relations, including bride purchase (Zvelebil 1996; Haarmann 2003c).

c. Are there traces of an old Indo-European population in Anatolia? When referring to the period of the seventh millennium $\mathrm{BC}$, the answer to this question is no. The oldest traces of the presence of a population in Anatolia which was definitely Indo-European comes from Assyrian sources $c .2000 \mathrm{BC}$ in which the Hittites are mentioned for the first time. The as- 
sumption that Anatolia was originally inhabited by a non-Indo-European population is more consistent with reliable data than the hypothesis of this region being the homeland of proto-Indo-Europeans. The non-Indo-European Hatti were the previous occupants of the later Hittite capital of Hattusa, and their culture is dated to $c$. 2500-2000 BC (Akurgal 2001. 4-18).

There is a Hattic substratum in the Hittite language, which proves that Hattic is the older language in the region, predating the presence of Hittite. In addition, there is a functional clue relating to the status of the two languages which provides evidence for the fact that the Hittites were late-comers. Hattic served as a liturgical language in the Hittite state cult, a traditional function of that language which was adopted by the Hittite priesthood. If the Hatti had come as immigrants to an area where the majority of the inhabitants were Hittites, the Hattic language would have never assumed the prestigious status in Hittite society which it did enjoy.

d. Is there any evidence for an old layer of Indo-European languages in Anatolia, dating to the seventh millennium BC? In fact, there is none. The oldest Indo-European languages which can be individualized in Anatolia from early inscriptions are Hittite, Luvian and Palaic (see Mallory and Adams 1997. 12-17 on Anatolian languages). In terms of their affiliation they form two groups: Hittite-Palaic and Southwest-Anatolian (Luvian). There are more recent cognate languages which belong to the latter group (i.e., Lycian, Lydian, Sidetic, Pisidian, Carian). If the Anatolian languages were the remnants of a much older layer of Indo-European in the region, one would expect their structures to reflect an overall pattern of archaic features.

Indeed, there are several major features of great antiquity in the Anatolian branch (i.e., the retention of a laryngeal phoneme, numerous heteroclita, a divergent verbal system), but these features do not signal a time depth extending to the seventh millennium BC. Since in Hittite, the major language of the Anatolian branch, cognate terms are found that date to the fourth millennium BC (see e), the final separation from the Indo-European continuum cannot have happened earlier than about $3500 \mathrm{BC}$.

The most convincing explanation of this puzzle is the assumption of a two-phase migration movement, not away from Anatolia but directed toward it. The speakers of the ancestral language of Anatolian, the bea- rers of the Suvorovo culture (c. 4500-4100 BC) in Moldavia and Bulgaria, came to the region with the first migration wave of Indo-Europeans from the east, that is, from the northern Pontic zone. The language of the Suvorovo people "would have been taken over and transmitted to Anatolia by the next wave of steppe immigrants (coming with wheeled vehicles), who formed the Ezero culture (c. 33002700 calBC) of Bulgaria" (Carpelan and Parpola 2001.64).

e. Is there any evidence for an early separation of the Anatolian branch of languages from the rest of the Indo-European stock? There is none. If ProtoIndo-Europeans had migrated from Asia to Europe, this process would be somehow reflected in the reconstruction of the Indo-European protolanguage. One would expect the most archaic layer of cognate terms in the cultural vocabulary to be found in Anatolian. However, this is not the case. Moreover, one would not expect lexical innovations in Anatolian which emerged in the fifth and fourth millennia $\mathrm{BC}$. And yet, in the vocabulary of Anatolian languages we do find cognate terms for the yoking of animals (cf. PIE *iugóm > Hit yukan 'yoke; couple, pair', Greek zugon 'yoke', Lat iugum 'yoke', Lith jungas 'yoke', etc.), for wheel and wheeled vehicles ( $c f$. PIE *Hwergh_ > Hit hurki- 'wheel', Toch A wärkänt 'wheel'; variant roots in other Indo-European languages), for wool ( $c f$. PIE *ul-na > Hit hulana 'wool', Olnd urna- 'wool', Lat lana 'wool', Goth wulla 'wool', etc.) and other items relating to weaving (Mallory and Adams 1997.640-641, 648-649, 655).

It is obvious that the Anatolian branch separated from the rest of Indo-European rather late. In any case, a connection between Hittite, Palaic or Luvian and the autochthonous population of Anatolia cannot be conclusively established.

The non-Indo-European languages left traces, in manifold transformations, in the lexical layers of ancient Greek. Hundreds of terms in various domains of the vocabulary were adopted as elements of the pre-Greek substratum in the circum-Pontic region (see Strunk 2003.86-96 for an overview of research in this field). In the archaeological record, the numerous relics of Aegean cultures are the most illustrative reminiscence of this old terminology. The expressions which are "connected by their content with the old Aegean culture, show clearly that the derivational types with the characteristic suffixal elements belong to a definite foreign layer in the Greek vocabulary" (Katičic 1976.55). 
Among the pertinent borrowings of pre-Greek origin, we find nouns, adjectives and verbs which represent foreign derivational types (Haarmann 1995. 44-47). The occurrence of verbs in the repertory of borrowings (e.g. ancient Greek iapto 'to throw', $d y$ namai 'to be capable, potent') points to the fact that the contacts between Greeks and the pre-Greek autochthonous populations were intensive. Most extensive is the pre-Greek layer in the domain of names for plants. A considerable number of borrowings are also found in terms for natural phenomena, utensils, clothing, social relations, handicrafts, etc.

The archaeological record shows continuity of settlement in the areas north of the Black Sea from the end of the Ice Age (beginning of the Holocene) into the Neolithic period. This means that the local populations were indigenous and that there was no migration from outside into those regions during that span of time. The people that lived there left their genetic 'footprints', which testify to ethnic diversity. On the genetic maps, two distinct genomic profiles are discernible (Map 2):

a genomic concentration in an area north of the Azov Sea which has been identified as the putative Indo-European homeland;

- a genomic concentration further north which has been identified as the homeland of Uralic populations.

The Neolithic cultures in the area of the Indo-European homeland (Seroglazovo culture) and the Uralic homeland (Agidel culture) demonstrate a continuity of lithic industries from the Mesolithic period (Mallory 1989.192-193; Parpola 1999.181-187). The homeland question both for Proto-Indo-Europeans

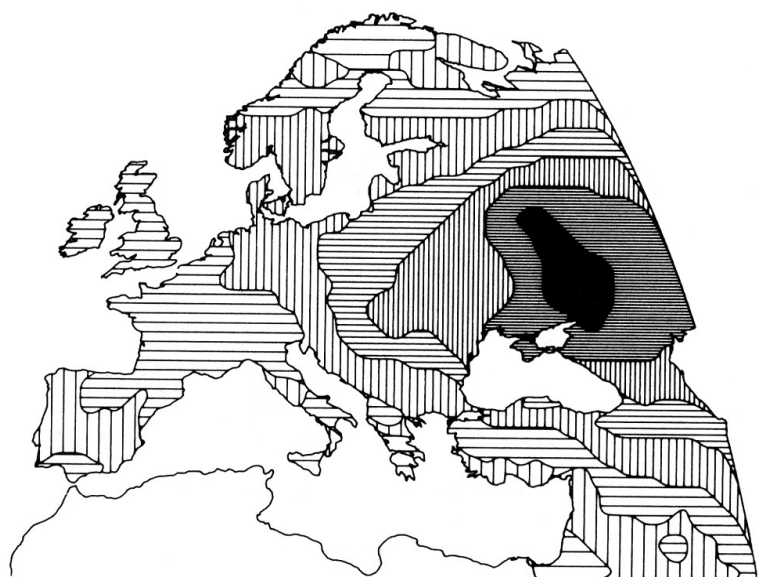

and Proto-Uralians has been much debated. As for the Uralic homeland, a nuclear area (Volga-Kama region) of more concentrated settlement and an extension of a more thinly populated area stretching from the Baltic to the Urals have been identified (Carpelan et al. 2001). There is a growing consensus focusing on the Caspian depression (with an extension into the region between Volga and Don) as the area of the Indo-European homeland. This hypothesis is seemingly being accepted by archaeologists and linguists alike as the most plausible of all homeland candidates (see Mallory 1997; Carpelan et al. 2001; Dergachev 2005.14-40; Haarmann 1998b; 2006a.154-160 for the history of this scholarly debate).

Historical linguistics has reconstructed grammatical structures and lexical roots which are similar in both Uralic and Indo-European. These linguistic traces attest to conditions of a long-term cultural and linguistic convergence when both Uralians and Indo-Europeans were still foragers. Since the genetic 'footprints' of the ancient populations in the northern Pontic area can be made visible (see Map 2), the linguistic reconstructions of an early period of UralicIndo-European convergence gain in profile. In the languages of both families, there is a core vocabulary and a set of grammatical forms which testify to a genealogical relationship (see Haarmann 2006a. 137-146 for the reconstruction of the Nostratic superphylum). These elements are not borrowed in either language family, but belong to the core inventory of forms inherited from oldest times (Tab. 1).

\section{The emergence of pastoralism in the steppe zone}

The eighth millennium $\mathrm{BC}$ brought about decisive environmental changes. According to Ryan and Pit-

Map 2. The genomic profiles of ancient populations north of the Black Sea. Left: the Indo-European genotype (after Cavalli-Sforza 2000.117); Right: the Uralic genotype (after Cavalli-Sforza 2000.114).

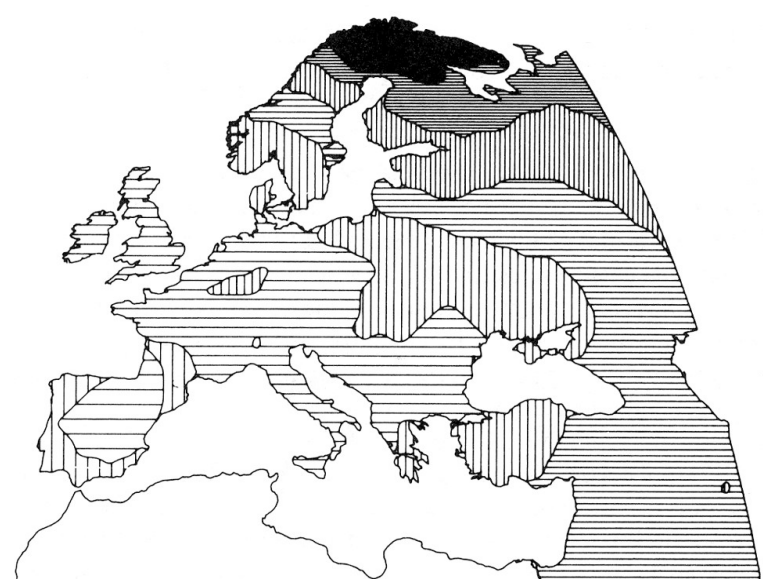


man (1998.157-158, 174-178), the circum-Pontic zone experienced a stage of progressive desiccation after the mid-tenth millennium BC. The second meltwater spike (beginning about $9400 \mathrm{BC}$ ) never reached the ancient Euxine Lake, and the aridification of the area north of the freshwater lake proceeded rapidly. The ecological preconditions for the beginnings of pastoralism among Proto-Indo-Europeans are found in the forest-steppe zone during this period. The ongoing process of desiccation in the northern Pontic zone caused an extension of the steppe zone in the south and a receding of the forest-steppe belt to the north.

These environmental changes had long-term repercussions on human ecology. Gradually, the development in the south shifted, economically, culturally and linguistically. This was a prolonged process that might have taken more than a millennium to unfold. The people in the southern steppe zone experienced a socio-economic transition from foraging to herding. Since the climatic effects of desiccation enhanced the transition to pastoralism in the Pontic steppe zone, the development there in the communities of Proto-Indo-European stock detached itself from the former socioeconomic, cultural and linguistic basis of convergence with the Proto-Uralians, resulting in the formation of a gravitational epicentre of ProtoIndo-European culture (as distinct from the ProtoUralian epicentre further north).

\begin{tabular}{|c|c|c|c|c|}
\hline a) & $\begin{array}{l}\text { *Indo-European/ } \\
\text { Indo-Iranian }\end{array}$ & $\begin{array}{c}\text { *Uralic/Finno-Ugric } \\
\text { (Finnish) }\end{array}$ & $\begin{array}{l}\text { Hungarian } \\
\text { equivalent }\end{array}$ & English \\
\hline & $\begin{array}{l}\text { 1. *wedh- } \\
\text { 2. *wegh- } \\
\text { 3. *doyn-<*do-*toye } \\
\text { 4. *mozge- } \\
\text { 5. *dh3k- } \\
\text { 6. *nomn- } \\
\text { 7. *wed- } \\
\text { 8. *kot- } \\
\text { 9. "sńew-, *sen-, *son- }\end{array}$ & $\begin{array}{l}\text { *wetä } \\
\text { *wiyge- } \\
\text { *toke-/Finnish tuo } \\
\text { "mośke-, *muśke- } \\
\text { "teke- } \\
\text { *nime } \\
\text { *wite, *wete } \\
\text { "kota } \\
\text { *sōne, *sine, *sene }\end{array}$ & $\begin{array}{l}\text { vezet } \\
\text { visz } \\
\text { hoz } \\
\text { mos } \\
\text { te-sz } \\
\text { név } \\
\text { viz } \\
\text { ház } \\
\text { ín }\end{array}$ & $\begin{array}{l}\text { leads } \\
\text { carries } \\
\text { brings } \\
\text { washes } \\
\text { makes } \\
\text { name } \\
\text { water } \\
\text { house } \\
\text { sinew }\end{array}$ \\
\hline b) & $\begin{array}{l}\text { Personal } \\
\text { pronouns }\end{array}$ & $\begin{array}{l}\text { Proto } \\
\text { Uralic }\end{array}$ & \multicolumn{2}{|l|}{$\begin{array}{l}\text { Proto- } \\
\text { Indo-European }\end{array}$} \\
\hline & $\begin{array}{l}\text { Singular } \\
\text { 1. pers. } \\
\text { 2. pers. } \\
\text { 3. pers. }\end{array}$ & $\begin{array}{l}*_{-m e} \\
*_{-t e} \\
*_{-s e}\end{array}$ & $\begin{array}{l}\text { "me- } \\
{ }^{*} \text { tu- } \\
\text { "se (Reflexive prot }\end{array}$ & un) \\
\hline & $\begin{array}{l}\text { Plural } \\
\text { 1. pers. } \\
\text { 2. pers. } \\
\text { 3. pers }\end{array}$ & $\begin{array}{l}* \text {-met } \\
*_{-} \text {-tet } \\
*_{\text {-set }}(?)\end{array}$ & \multicolumn{2}{|c|}{$\begin{array}{l}\text { "mes/*nes- } \\
\text { "yu- } \\
\text { no reconstructed protoform }\end{array}$} \\
\hline
\end{tabular}

Tab. 1. Linguistic convergences between Proto-Uralic and ProtoIndo-European. a) Convergent lexical roots (after Makkay 2001. 320); b) Convergences in the pronominal system (after Hajdú and Domokos 1987.234-235).
In the course of the seventh millennium $\mathrm{BC}$, the differences between foraging, as the major type of protoUralian economy, and pastoralism, as practiced by Proto-Indo-Europeans, became more marked and the geographical zone of each type of economy more concentrated.

The process of the dissolution of the former basis of convergence and of the formation of the Proto-IndoEuropean epicentre was of local coinage. This means that - beyond the assumed internal population movement in the Pontic steppe zone after the flood there was no population influx from either the steppe zone of central Asia or from the region of agrarian population of Ukraine and central Europe.

Eventually, the two epicentres with their differing ethnic stock also became characterized by divergent proto-languages, which can be reconstructed with the methods of historical-comparative linguistics (see Beekes 1995.124-257 for Proto-Indo-European, Hajdú and Domokos 1987.179-271 for Proto-Uralian).

At first sight, it may seem problematic to conflate a linguistic term with the assumed speakers of a language, such as to identify the northern foragers (with Uralian cultural patterns who are assumed to have spoken Proto-Uralian) as 'the Proto-Uralians,' and to identify the pastoralists further south (with IndoEuropean cultural patterns who are assumed to have spoken Proto-Indo-European) as 'the Proto-Indo-Europeans.' And yet, the archaeological record indicates the continuity of distinct cultural patterns in each area where, at a later date, the presence of Indo-European languages (in the Pontic steppe region) and Uralian languages (further north) are documented by linguistic interferences (Haarmann 1996.910; Koivulehto 2001). Since there is no evidence of population influx from outside, the local Neolithic populations must be ancestral to the later Uralian and Indo-European speakers of each region.

The transition from a foraging to a pastoralist economy was accompanied by changes in life-styles. As part of the process of Neolithization, this transition has been a matter of much debate. There are those who explain the shift to herding and pastoralism 
as resulting from the spread of technologies relating to the 'agricultural package' (technologies of plant cultivation and of stock-breeding) that were introduced to the steppe zone from the northwestern Pontic area. The term 'agricultural package' has been defined as "the sum of traits that appear repeatedly in the Neolithic assemblages of $S W$ Asia, Anatolia and SE Europe" (Cilingiroglu 2005.3). Others see a direct transition without the participation of agrarian technologies and relating forms of cattle-raising.

As far as the Proto-Indo-Europeans and their homeland are concerned, two basic assumptions have been elaborated which stand in absolute contradiction to one another.

Pastoralism in the steppe zone emerged independently and its origins are not associated with agriculture

Although the archaeological evidence for this early transition is scarce, historical linguistics has reconstructed an old layer of common lexical roots for the domain of pastoralism. This terminology forms part of the core vocabulary of Proto-Indo-European, the reconstructed common basis from which all Indo-European languages derive. The old layer of terms for herding "appear to be widespread across the entire range of IE [Indo-European] stocks." (Mallory and Adams 1997.7) (Tab. 2).

While the Proto-Indo-Europeans experienced their shift to a pastoralist economy, the Proto-Uralians, in their homeland in the forest zone further north, continued to live on foraging. Therefore, such terminology relating to early pastoralism reconstructed for Proto-Indo-European is absent from the basic vocabulary of ProtoUralic.

An inspection of the core terminology of pastoralism that can be reconstructed for Proto-Indo-European reveals that the diagnostic terms referring to goat and sheep - the oldest known animals that played a role in Indo-European herding - as well as to field and herd are either widespread in the branches of this language family (see Tab. 2, nos. 1, 2, 5, 6 and 9), or seem to be best preserved in the eastern Indo-European languages (see Tab. 2, nos. 3, 4, 7 and 12). The wide distribution is an indication of the general importance of this vocabulary for the early Indo-Europeans. The persistence of the old diagnostic terms, especially in the eastern Indo-European languages, points to the steppe zone as the area of pastoralism's origin.

Based on observations about the lack of an old layer of agricultural terminology in the Indo-Iranian branch of languages, it was assumed that the pastoralists who spoke such languages knew nothing about agriculture. Given the lack of old agricultural terminology in this major branch of Indo-European, it is tempting to deny the existence of old agricultural terms for the Indo-European protolanguage.

The meaning of the lexical material referring to agriculture is, in many cases, diffuse and does not allow the reconstruction of a very old layer. For example, there is no old term for 'wheat' and no general term for 'barley'. The more extensive agricultural terminology becomes in historical languages, the younger is the lexical layer (often relating to stages of linguistic development of the fifth millennium $\mathrm{BC}$ or later).

To sum up, the linguistic and archaeological evidence speaks in favor of pastoralism as having developed independently of farming in the steppe zone of southern Russia.

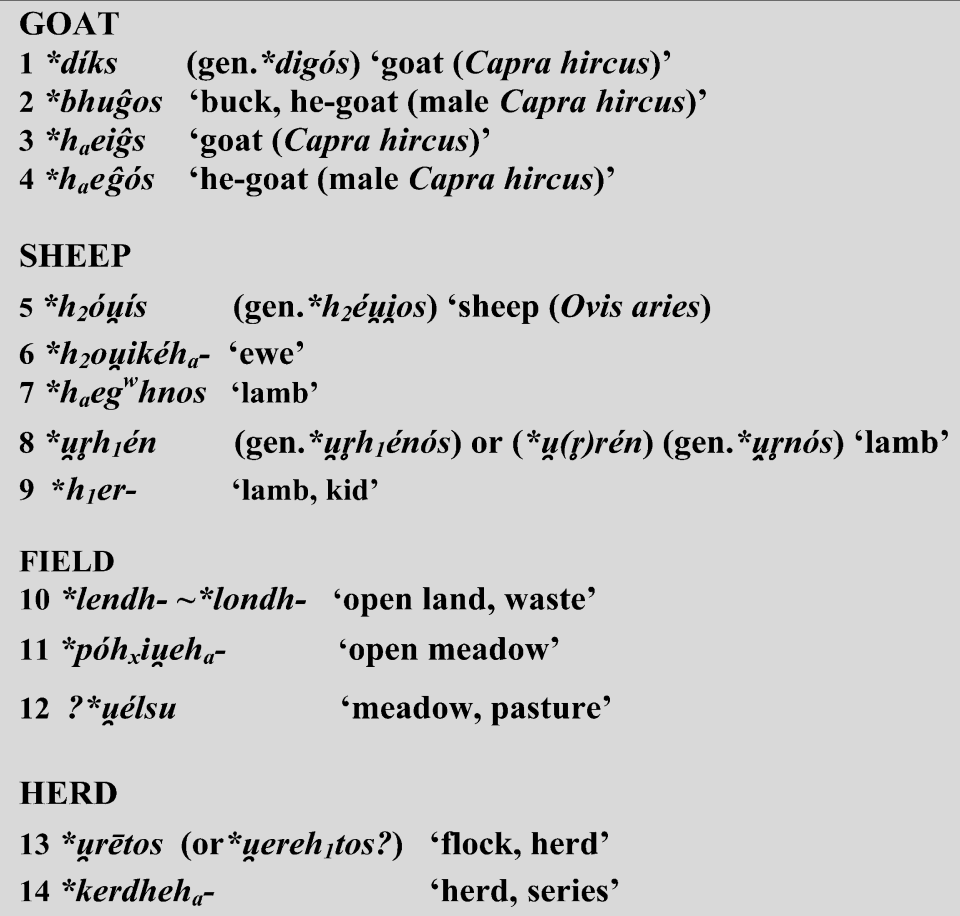

Tab. 2. Diagnostic terms of pastoralist economy in the Proto-IndoEuropean lexicon (after Mallory and Adams 1997). 


\section{Is pastoralism an offshoot of a farming eco- nomy?}

This view has been advocated by Renfrew (2002a. 4-7) and others. It is argued that hunter-gatherers would not have experienced a transition to pastoralism without a previous stage of animal husbandry, and this would have been intrinsically associated with farming practises. Renfrew categorically denies the possibility that hunter-gatherers might have started to herd wild sheep and goats - the essential animal domesticates - without the parallel stage of farming. It is admitted that the horse was used by hunter-gatherers and that the early users might have been horse-herders. But it is denied that these horseherders could have been horse-breeders.

It is hazardous to discard, in a discussion of Neolithic economies of the seventh and sixth millennia BC in eastern Europe, any alternative a priori (e.g. negating a direct transition from a foraging to a pastoral economy). There are well known examples of a transition to herding and breeding without the participation of farming practises from the historical period.

The earliest traces of reindeer herding date to the fifth millennium BC, as evidenced in rock carvings at Alta in northern Norway (see Helskog 1988 for the pictures of Bergbukten I). Among the Saami people of the North, reindeer herding and breeding developed as an independent economic system, and there was no influence from farming communities with animal husbandry which would have provided the incentive for breeding. Similar processes of a transition from hunting and gathering to reindeer herding and breeding evolved in northern Siberia among the ethnic groups of Samoyedic, Altajic and Paleoasiatic stock (Funk and Sillanpää 1999.16, 39, 62, etc.).

In the case of the Proto-Indo-European context, a prominent factor gives additional weight to this assumption of a direct transition, and this is the chronological continuum. Pastoralism can be readily assumed to have emerged no later than the seventh millennium BC. However, agriculture did not reach the eastern Pontic zone prior to $5500 \mathrm{BC}$ (see the isochrones in the map presented by Carpelan and Parpola 2001.63). Pastoralism in the region clearly antedates the practise of farming. The lexical layer of Proto-Indo-European terms for herding is older than the terminology of the 'agricultural package' which arrived on the western fringes of the steppe zone at a later time.

\section{Diagnostic items of early Indo-European cul- ture}

The horse is of special significance for the Indo-Europeans and their culture. There is consensus about this basic fact among scholars. What is disputed, though, is the process of the domestication of this animal and since when it was used for riding. A lexical root for 'horse' (*hekuos in simplified transcription) can be reconstructed for the Proto-Indo-European vocabulary, and this root is common for the equivalents in all the local languages of this phylum (Tab. 3). There is a linguistic feature which makes the issue of the horse and all that is related to it difficult. In the Indo-European terminology, no difference is made between the wild and the domesticated horse.

According to the original version of the Kurgan hypothesis, propagated by Gimbutas, it was assumed that the Indo-Europeans left the steppes on horseback, and that it was the military supremacy of mobile horse-riders which gave the pastoralists the edge during their expansions. However, horse-riding is not attested for the fifth millennium BC. The archaeological record of the steppe zone of southern Russia points to $c .5000 \mathrm{BC}$ as an early date for the appearance of the horse motif in imagery (Gimbutas 1991. 353). The existence of imagery relating to this prominent animal as such does not entail that the horse was already domesticated at that time. The imagery might well relate to mythical conceptualizations of wildlife among the early pastoralists.

In the beginnings, the wild horse might have been hunted for its meat. Most probably, the domestication of this animal to become used for riding was a prolonged process (Levine et al. 1999). And yet, it seems reasonable to assert that humans "would rapidly have recognized the greater potentiality of the horse as a means of transport and a powerful cultural symbol" (Dolukhanov 2002.18).

Judging from ethnographic literature and from empirical observations of traditional herding in recent nomadic cultures, the role of the horse may at first have been marginal for the socio-economy and its significance might have increased gradually. Shishlina (1997) draws attention to a certain custom among herders of the modern steppe zone in Kalmykia who keep horses as draught animals and, for another special purpose. In winter, when the snow cover of the pasture may be too hard for sheep and goats to find fodder, the horses break the cover with their 


\section{HORSE}

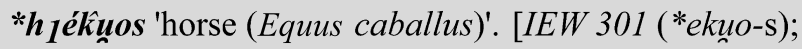

Wat 16 (*ekwo-); GI 463 (*ekn wos); Buck 3.41]. OIr ech

'horse', Wels ebol 'colt', Gaul epo- 'horse', equos (name of a month), OLat equos 'horse', Lat equus 'horse', Venetic (acc.) ekvon 'horse', ON jōr 'horse', OE eoh 'horse', Goth aílva-tundi 'brambles' (= 'horse-thorn), OPrus aswinan 'horse-milk', Lith

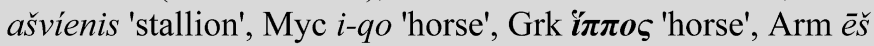
'horse', HierLuv azu(wa) 'horse', Lycian esbe- 'horse', Av aspa'horse' OPers asa- 'horse', Sogd 'sp 'horse', Oss joefs 'horse', OInd áśva-'horse', TochA yuk 'horse', TochB yakwe 'horse'. Cf. The derivative *hlekuó-t- in Lat eques (gen. equitis) 'rider', Grk $\boldsymbol{i} \pi \boldsymbol{\pi} \boldsymbol{\delta} \boldsymbol{\tau} \boldsymbol{\eta} \varsigma_{\text {'rider'. }}$

Tab. 3. The lexical root for 'horse' in Proto-Indo-European and its derivations in individual Indo-European languages (after Mallory and Adams 1997.273-274).

strong hoofs and provide access for the smaller animals to the grass below. Such a function can be conjectured to have been the first possible use of the horse by the Kurgan pastoralists.

At a later stage, the horse was certainly used as a draught animal. This can be assumed for the migrants who, coming from the eastern steppe, arrived at Durankulak, and later at Varna in the northwestern Pontic zone. The movement of the Kurgan people from their homeland in the Pontic-Caspian region to the southwest can be traced on the basis of the spread of a diagnostic cultural item, the horseheaded sceptre (Fig. 1).

Those groups of steppe people who reached the northwestern Pontic region introduced a technological innovation: wheeled wagons. Horse-riding became a custom at a later date. Although this means that the first migrants who made their incursions in the region where the agriculturalists settled were not horse-riders, it does not follow that the Kurgan hypothesis would lose its value as an explicative model. The advance of a powerful élite imposing their order on the local population would be a realistic scenario to explain the early stage of movements of the Kurgan people (Kurgan I).

\section{Non-Indo-Europeans and Indo-Europeans: sce- narios of contact and conflict}

The drifting apart of the socio-economic systems caused a shift in culture and language, too. This meant the gradual dissolution of the older network of Nostratic convergences, with the cultural as well as linguistic differences between Uralic and Indo-European becoming more marked in time. The Proto-Indo-Eu- ropeans who roamed the steppe in search of pastures for their herds had a life-style that differed markedly from that of the Proto-Uralians who had continued as hunters and gatherers in the northern forest zone.

The population of the south, the Proto-Indo-European pastoralists, did not experience a development of their culture and language in isolation. From the earliest times of the formation of the Indo-European complex the pastoralists engaged in contacts, social interaction and trade relations, with their neighbors in the north (Proto-Uralians) and further south (Proto-Northern Caucasians).

\section{Conflict-free contacts between pastoralists and hunter-gatherers in the sixth and fifth millen- nia BC}

Despite the differences in life-styles, the hunter-gatherers from the north maintained contact with the pastoralists from the south. The social interaction of populations in the former Nostratic zone of convergence changed its nature and transformed into patterns of contact between bearers of distinct cultures and speakers of distinct languages. The contacts which the Proto-Indo-Europeans established with the northern neighbours date to the sixth and fifth millennia BC. Evidence for these early contacts of Proto-Uralians with Proto-Indo-Europeans are the loanwords which were borrowed from Indo-European into the Uralic vocabulary (Tab. 4).

The movement of lexical borrowing was unilaterally directed from the Indo-European south to the Uralic north. This observation supports the assumption that the language of the pastoralists and their culture were considered to be prestigious by the Proto-Uralians. Judging from the distribution of the old IndoEuropean loanwords in the sections of the Uralic lexicon it can be concluded that the Indo-Europeans engaged in trade (see the borrowing for the idea 'to sell') and had prestigious goods (such as honey) and technologies (such as spinning and construction) to offer to the hunter-gatherers of the north.

There were also contacts with the southern neighbours, the indigenous population of the Caucasus. Most probably, interactions between Proto-Indo-Europeans and local people in the northern Caucasus 
began to unfold in the early fifth millennium $\mathrm{BC}$. Apparently, the same kind of prestige that the ProtoIndo-Europeans enjoyed with their Uralian neighbours also dominated contacts with the people in the south. Among the Indo-European borrowings in northern Caucasian languages, we find diagnostic terms of pastoralism such as expressions for 'goat' and 'cattle', lexical evidence for trade relations (i.e., 'payment'), and for the transfer of trade goods (i.e., 'axe', 'ring'); (Tab. 5).

The scenarios of contact involving Proto-Indo-Europeans, Proto-Uralians and Proto-Caucasians unfolded under the auspices of peaceful relations, with no recognizable agenda of conflict. As is known from ethnographic literature and from comparisons of the
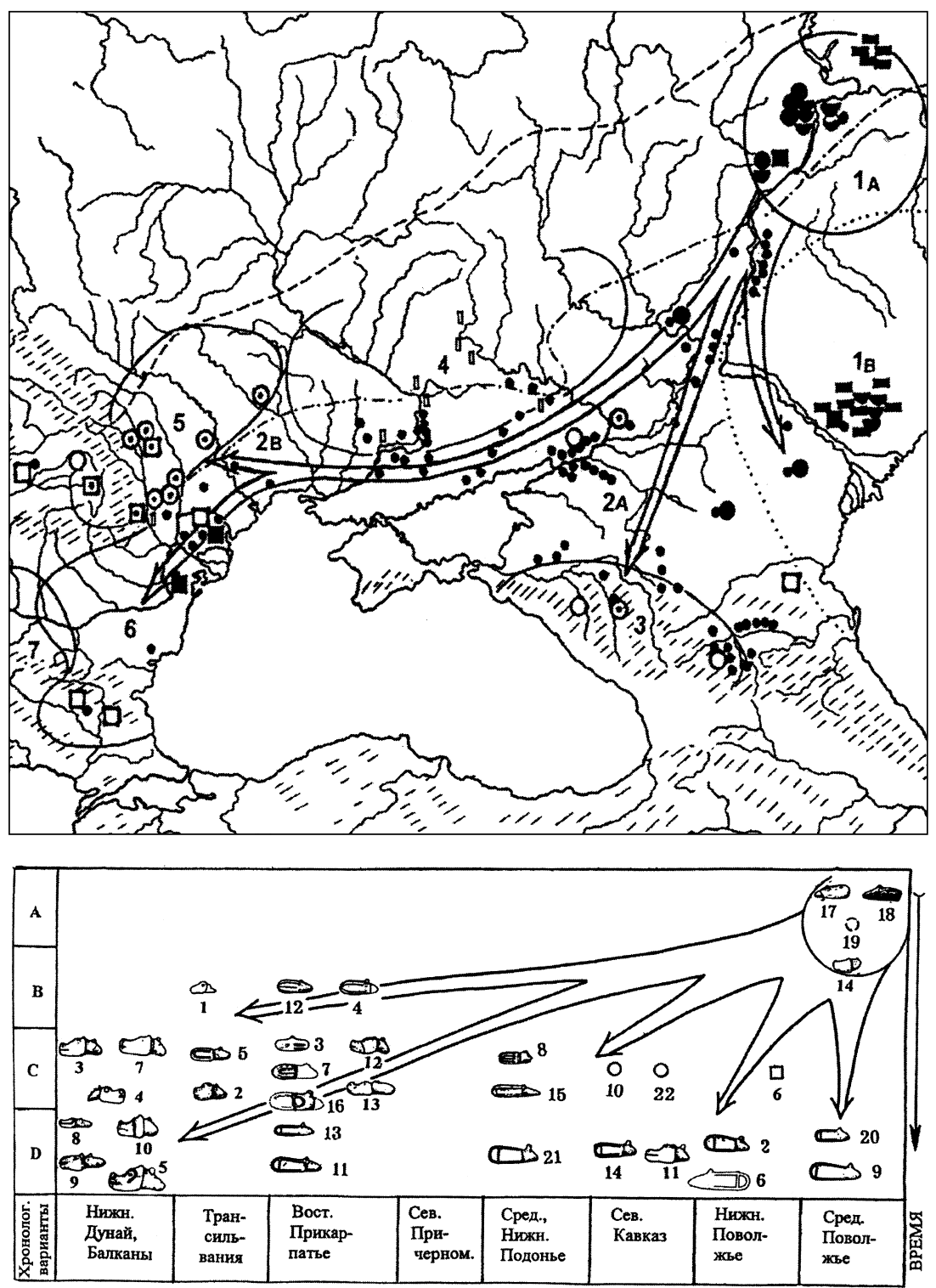

Fig. 1. The distribution of horse-headed sceptres in the steppe zone (after Dergachev 2005.85, 88). The geographical expansion of distribution (upper) and schematic spatio-temporal trajectory (below). world's cultures, contacts between pastoralists and hunter-gatherers are, in principle, friendly in nature, and this is because there is no competition over resources. The hunter-gatherers do not need the pastures of the pastoralists, and there is no advantage for the pastoralists to move with their herds into the hunting-grounds of foragers. As a rule, hunter-gatherers assign a higher prestige to the culture of pastoralists and to their trade goods.

\section{Contacts between pastoralists and agricultura- lists with agendas of conflict}

On the western periphery of the steppe, where the terrain that was frequented by the pastoralists and their herds bordered the area of arable land (i.e., in southern Ukraine), the boundaries between the two economic systems of pastoralism (the eastern tradition) and of agriculture (the western tradition) began to float soon after $c .5000 \mathrm{BC}$. The initial contacts between pastoralists and agriculturalists may have been peaceful, but things changed when the socioeconomic sphere of the Cucuteni-Tripillye culture experienced its expansion to the East and new agrarian settlements were established in areas formerly frequented by pastoralists.

The direct consequences of this expansion were an infringement of the movements of the pastoralists and a reduction of their resources, the pastures that had been turned into fields. And yet, there were other consequences that had an even stronger impact on the sustainability of pastoralism in the contact region. And this had to do with the ways herding as a socio-economic system operates. A true understanding of the ways of pastoralist economy is not seldom hampered by stereotyping views that outsiders carry in their minds. 
PIE. *meyH- 'give, sell' > U.*mexe-, e.g. Finnish myydä

PIE. * $m e d^{h} u$ - 'honey' > Finno-Ugric *mete, e.g. Finnish mesi (genitive meden)

PIE. *ket tro- 'spindle' > Volgaic-Finnic *kesträ, e.g. Finnish kehrä, dialectal keträ (PIE. *ket tro- has been preserved only in the Aryan branch of IE.: i.e. ProtoIranian *castra > Pashto cã̌sai, Proto-Indo-Aryan *cattra > Sanskrit cattra; (Parpola 1995,1.2)

PIE. *seitu- 'bridge, floorboard' > Mordvin-Permian *se(j)t $V$, e.g. Erza-Mordvin sed', Zyryan sod

PIE. *pewH-eno- 'sieve' > Proto-Permian *pe(w)šen(V), e.g. Udmurt pü̆, Zyryan pož

PIE. *lond $d^{h} o$ - or *lomd $d^{h}$ o- 'field, plain' > Proto-Permian *lonta/*lomta, e.g. Finnish lansi (stem lante-).

Tab. 4. The transfer of Proto-Indo-European (PIE) terminology to Uralian (U) (after Haarmann 1996.10).

"The free-moving, chaotic 'nomad' is a myth. The most complex system regulates these movements by strict formal schedules, restrictions on numbers and types of animals, reserving or deferring pastures, assigning members to particular pastures and controlling the amount of time spent in one pasture. Thus, the organisational complexity varies greatly between different pastoral groups" (Niamir 1995.245).

The prehistoric expansion of Tripillye settlements into the steppe zone was more than a territorial occupation of former pastures; it caused more disturbance than an infringement of the movements of the pastoralists. The consequences of this expansion culminated in a shake-up of the nomadic socio-economic system and in a threat to the accessibility of resources. The magnitude of this threat might have been felt differently in the regional groups of pastoralists, but, in principle, the world of the agriculturalists exposed itself to the herders as harmful to their socio-economic sustainability.

Given these unfavorable conditions, the expansion of the agrarian system of subsistence to the east caused increasing frictions between agriculturalists and pastoralists, stirring up ever more competition over the exploitation of the terrain. During the first half of the fifth millennium $\mathrm{BC}$, under the pressure of growing socio-economic stress in the local communities, there are signs of clashes and even warfare between the western agriculturalists and the steppe people, as evidenced by layers of ashes and an increased number of arrow-heads in the archaeological record of the easternmost settlements of the Cucuteni-Tripillye culture.

By the middle of the fifth millennium $\mathrm{BC}$, ever more settlements on the eastern periphery of the Cucuteni-Tripolye culture (Cucuteni-Tripillye, respectively) $\mathrm{A}$ and $\mathrm{B} 1$ periods were fortified, and the frequency of arrow-heads in the archaeological record increases. The end of the Tripillye culture is marked by its replacement, in the northern region, by the Globular Amphora culture and, in the steppe region, by the late Pit-Grave culture.

"In the latter case, the question inevitably concerns Gimbutas' third wave of steppe invasion. However, if the equally abrupt increase in the number of artificially-fortified settlements of the final Tripolye period is due to the threat of invasion by other cultures, may we infer a similar quantitative increase in fortified settlements during the Cucuteni A-Tripolye B1 period which is attributable to similar circumstances? Following the principle of analogy, there can be only one explanation - invasion, and therefore, this completely confirms Gimbutas' idea of the first wave of steppe livestock breeders." (Dergachev 2002.102)

Arguably, the migrations of the steppe people find their ultimate motivation in elementary counterreactions to these scenarios of unrest.

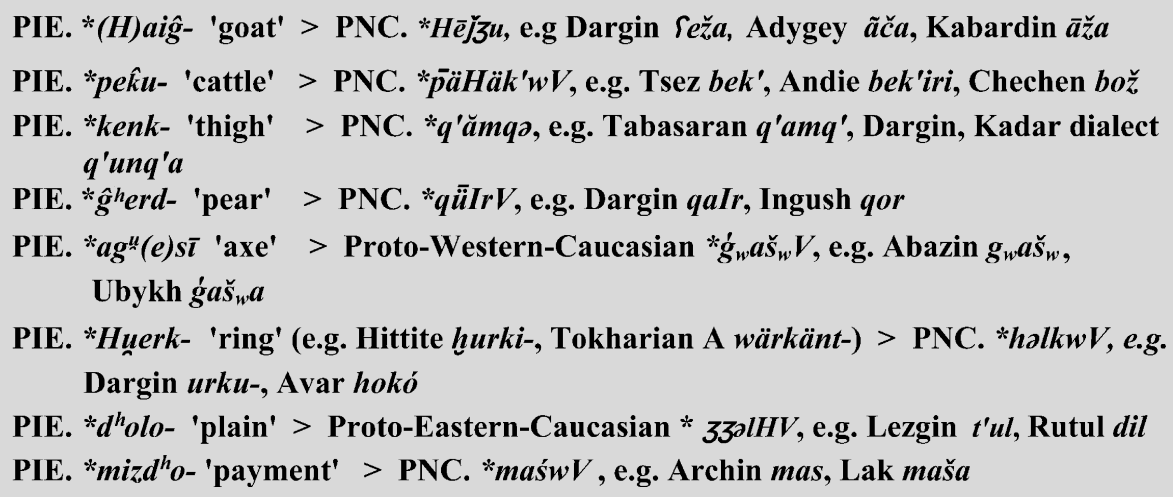

PIE. *Huerk- 'ring' (e.g. Hittite hurki-, Tokharian A wärkänt-) > PNC. *holkwV, e.g. Dargin urku-, Avar hokó

PIE. *dholo- 'plain' > Proto-Eastern-Caucasian * 33 lHV, e.g. Lezgin $t^{\prime} u l$, Rutul dil PIE. *mizd $d^{h}$ - 'payment' > PNC. *maśwV, e.g. Archin mas, Lak maša

Tab. 5. The transfer of Proto-Indo-European (PIE) terminology to Proto-Northern Caucasian (PNC) (after Haarmann 1996.11). 
Early movements of steppe people to the west and the nature of Indo-European migrations

It is reasonable to assert that the early pastoralists in the Pontic-Caspian zone were challenged by the advance of agricultural practises into the region, and their reactions to this 'intruding' factor triggered a chain reaction: the great Kurgan migrations. Marija Gimbutas (1974; 1991; 1992) coined this overarching term to define the movement of the steppe people, and to identify the bearers of the earliest recognizable Indo-European culture, that of the people who built huge burial mounds, called kurgan (a word of Turkic origin).

Gimbutas assumed that the thrust of the migrations, which she imagined as movements of populous groups, was effected by groups of horse-riders. If it holds true that the pastoralists were highly mobile, then this mobility on horse-back would be a decisive asset of any of their military operations to ensure their migratory advance. The assumed mobility of horse-riding pastoralists became the target of criticism intended to discredit the Kurgan hypothesis. Admittedly, there is no evidence for the use of the horse as a riding animal in the fifth millennium BC. The validity of the Kurgan hypothesis, however, is not at the mercy of the horse as a factor to explain the swiftness and success of the migrations.

The most crucial factor in any approach to explaining the movements of the steppe people is a refinement of the key concept 'migration'. Migration is a comprehensive notion, with various conceptual facets in the wide array of its overall meaning (BellFialkoff 2000). Migration does not exclusively mean 'mass movement'. The process of Indo-Europeanization of the northwestern and western Pontic region between $c .4400 \mathrm{BC}$ (beginning of the first wave) and $c .3000 \mathrm{BC}$ (end of the third wave) was not necessarily the result of massive population movements.

The cultural and linguistic changes could well have resulted from the exertion of control of a ruling élite over people and territory either by intermarriage into families of local dignitaries, or by assuming power through conquest. As a rule, the culture of the élite dominates, and its language is more prestigious than that of the local population, eventually resulting in the assimilation and language shift of the latter. In this process, elements of the local language are absorbed as a substratum by the dominating language. The same holds true for cultural patterns, like the survival of cults of female divinities among the ancient Indo-European peoples in southeastern $\mathrm{Eu}$ rope (i.e., Thracians and Illyrians).

In the northwestern Pontic region, the incursions of the steppe people produce permanent patterns of change. Judging from richly equipped graves, a new social élite makes its appearance at Durankulak (northeastern Bulgaria) around $4600 \mathrm{BC}$ and, a hundred years later, the tradition of burials also changes at Varna. There, insignia such as a horse-headed sceptre and other ceremonial items of political power provide evidence "of the spread of steppe tribes from the east to the west and in the 'Kurgan' model of Indo-European origins is seen to reflect the first wave of Indo-Europeans from their homeland in the steppelands of the Ukraine and south Russia" (Mallory and Adams 1997.557) (Map 3).

Durankulak, Varna and other sites provide 'diagnostic' socio-cultural profiles for the establishment of social hierarchy and élite power typical of nomadic societies.

\section{Fusion processes of Non-Indo-European and Indo-European elements: patterns of domi- nance and indominance}

Fusion processes of cultures and languages may be compared to the endeavour to reconstruct a ship while floating in the water. You can never succeed in replacing everything old by everything new because the vessel has to stay afloat. Therefore, there will always be old elements that persist, regardless of how many new elements are introduced. The Indo-Europeanization of the cultures and languages of Europe did not produce strategies of 'replacement', but patterns of fusion in which older constituents (of non-Indo-European origin) and younger elements (of Indo-European coinage) intermingled.

The results of such fusion differ greatly in the regions where non-Indo-Europeans and Indo-Europeans interacted, and they are specific for any local culture and language. According to the parameter of 'dominance-indominance' the following major configurations can be identified in the cultures and languages of Europe.

\section{Scenarios of a dominance of Indo-European elements over non-Indo-European elements}

The fusion process in which the cultures of Indo-Europeans and of non-Indo-Europeans participated in southeastern Europe "...not only involved those ele- 
ments that survive in the archaeological record, but affected the nonmaterial dimensions such as stories, songs, myths, rituals, and beliefs which function within complex webs of meaning" (Marler 2005.60). This holds true for language, also, in this case for the fusion of linguistic elements of Indo-European and of local non-Indo-European origin. I refer here to the Indo-European language with the longest written record, Greek. The earliest records in Mycenaean Greek, written in Linear B, date to the seventeenth century BC (Haarmann 1995.125126).

Greek is categorized as an Indo-European language. However, its lexical structures and its system of word formation differ markedly from other cognate languages such as Latin, Persian, Sanskrit, etc. The reason for this is the pre-Greek substratum, a layer of old lexical borrowings and formative elements from the ancient non-Indo-European languages that were spoken in southeastern Europe before the advent of the Indo-Europeans. In ancient Greek, the old loanwords do not represent a lexical inventory which was isolated from the Greek vocabulary inherited from IndoEuropean. Borrowed and indigenous lexical items form a symbiotic network of expressions. This can be illustrated for the various terminologies, of spinning and weaving for one.

Evidence for the vertical loom dating to the pre-deluge era cannot be given, and its appearance during the seventh millennium BC is scarce, although evidence does exist from Çatalhöyük in Anatolia, Greece, and the Tisza valley in Hungary. Nevertheless, the presence of loom weights in cultural strata of the seventh and early sixth millennia BC demonstrates the existence of a similar textile producing technology throughout Anatolia and southeastern Europe. Later, textile production proliferated and spread to various regions. "In short, we might be seeing connections southward into the Aegean, as well as northwestward into Hungary." (Barber 1991.98)

It is noteworthy that in ancient Greek weaving terminology there is an abundance of borrowings that have survived from pre-Greek times. These borrowings of non-Indo-European origin are not isolated in the lexicon, but have been integrated into the language, forming a broad layer of terminology that is symbiotically interconnected with expressions based on Indo-European cognates.

In the lexical structures, two integrational patterns can be discerned that indicate the fusion and persistence of pre-Greek terms within Greek terminology (Tab. 6).

One is the duality of pre-Greek (non-Indo-European) and Greek terms (of Indo-European origin):

a. In the entire terminology relating to weaving, there are clusters of expressions with a specialized meaning that stem from a non-Indo-European source, and others which are inherited from the bulk of Indo-European cognates.

b. The other integrational pattern is synonymity of pre-Greek and Greek terms, which provides the ancient Greek language with a great potential for stylistic variation.

Another domain where pre-Greek (=non-Indo-European) terms have survived in ancient Greek is metallurgy (Fig. 2). The oldest gold treasure of the world is known from Varna and dates to $c .4500 \mathrm{BC}$, to the times of the earliest Indo-European incursions in the northwestern Pontic region.

Since some basic non-Indo-European expressions are attested for the terminology of metal-working in Greek, this is evidence that this technology was not introduced to the region by the Indo-Europeans, but had been in use before the Kurgan migrations. As specialized terms, some of these loanwords of preGreek origin have been mediated to our modern 
languages via Greek civilization, among them, metallon metal and kaminos furnace. The archaeological term Chalcolithic Age is comprised of two elements of the pre-Greek substratum, khalkos copper and $l i$ thos stone (Hofmann 1966).

Another area of contacts of cultures and languages of different stock, non-Indo-European and Indo-European, is Tuscany in Italy. On the historical map showing the spread of human genes, the genetic 'footprint' of the pre-Roman population (i.e. the Etruscans) is recognizable as a divergent genomic profile (Cavalli-Sforza et al. 1994.278-279). The most prominent non-Indo-European language of ancient Italy, Etruscan, was not simply 'replaced' by Latin, but influenced the colonial language of Roman supremacy, and later Italian, in manifold ways. In the cultural vocabulary of Latin, there is a significant number of Etruscan expressions (Breyer 1993). Among the terms which Latin borrowed from Etruscan are atrium atrium house, elementum element (original meaning: 'letter of the alphabet'), persona person, individual, populus people and others, and many of the old loanwords have been transferred to the lexicon of modern European languages.

Still today, Etruscan habits of pronouncing certain consonants are still recognizable in the sound structure of the Italian dialect in Tuscany. In the area between the rivers Arno and Tiber, called 'Gorgia to- scana' (literally 'Tuscan throat'), the consonants k, $\mathrm{p}$ and $\mathrm{t}$ are regularly aspirated (to be transcribed as $\mathrm{h}, \mathrm{ph}$ and th): e.g. Tuscan poho little (for standard Italian poco), lupho wolf (for lupo), ditho finger (for dito); (Haarmann 2003a.344-345). The corresponding consonants in Etruscan were aspirated. Most probably, the habits of pronouncing among those Etruscans who assimilated to Latin continued among local people and were transferred to Italian, the daughter language of Latin, that originated in the early Middle Ages.

\section{Scenarios of a balanced distribution of Indo- European and non-Indo-European elements}

Speakers of Indo-European came in contact with Uralic peoples in the southern coastal region of the Baltic Sea. These were long-term contacts with far-reaching repercussions. Gradually, the speakers of Uralic were driven to the Northeast or they were assimilated. Although this meant an ethnic Indo-Europeanization of a region with a formerly Uralian population, in the languages that were involved in the contact, traces of a mutual influence are clearly recognizable.

The stress in Germanic languages is on the first syllable of a word, unless the word is a loanword or is coined on borrowed elements from another language. Deviant from the principle of the first-syllable stress is a word such as English 'replácement', formed on the basis of elements of Latin origin, with the stress on the second syllable. While Proto-Indo-European had a free stress, first syllable stress is an innovation in the Germanic languages. The change of the stress pattern is an Uralic substratum, that is, it stems from contacts with Uralic languages, where first syllable stress is the rule (Suhonen 1995).

The Baltic-Fennic languages that continue the tradition of Uralic in the Baltic region 


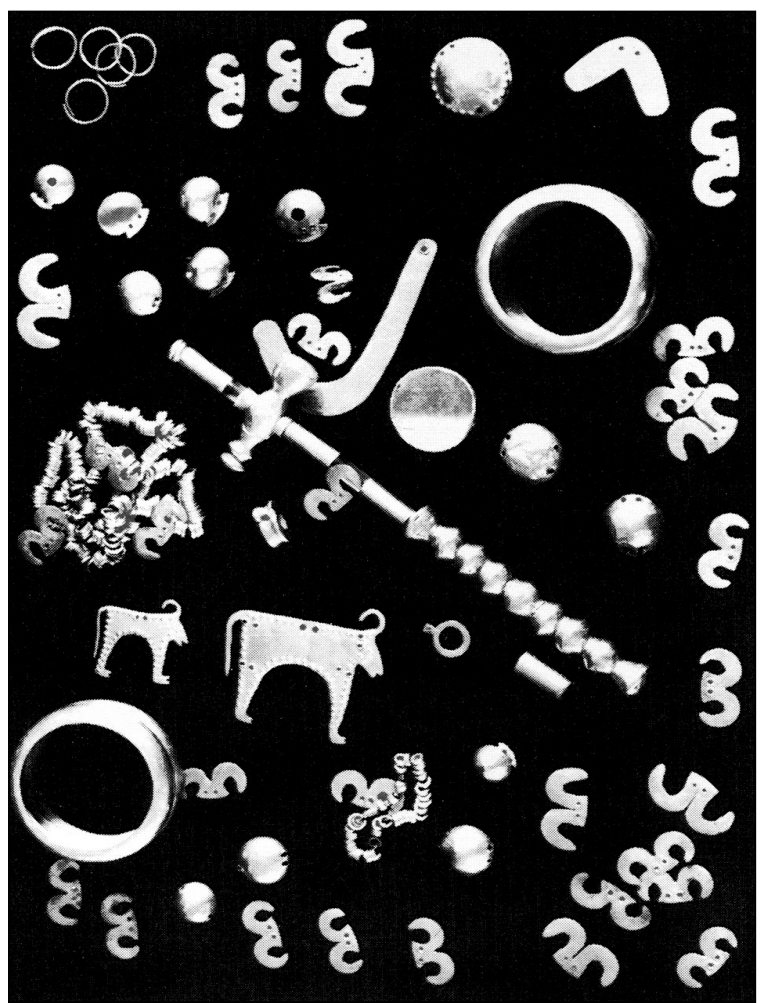

Fig. 2. Objects made of gold from the cemetery of Varna (c. 4500 BC; after Gimbutas 1991.120).

know a morphophonetic phenomenon which is called 'gradation' and unknown in other Uralic languages. Uralic languages operate with techniques of the agglutinative type, which means that formative elements are associated with the word stem in a way that the structure of the stem does not change (e.g. Hungarian ház house: házak houses: házakban 'in houses': házaimban 'in my houses', with the unchanged stem form ház). In Baltic-Fennic languages, the stem of words may change like in Indo-European languages of the inflectional type.

Among the most prominent properties of the Finnish sound system is regular alternation of the word stem, or to be more precise: changes within the stem which occur in conjunction with the addition of specific formative elements (Haarmann 2003b.878-882). These alternations (called in Finnish astevaihtelu 'gradation') are governed by a multiple set of specific rules which cause structural changes in the stems of words. Altogether, there are 130 stem classes. Of these, 85 are declension classes (of nouns), and 45 are conjugation classes (of verbs). Attempts to reduce the number of classes to a few or only one have so far been unsuccessful.

As for the phonetic features which underlay the manifold variations of the word stem, these can be ca- tegorized as follows: consonant gradation, total or partial consonant assimilation, vowel mutation, and vowel loss. The operation of these realizations of change may occur singly (simple alternation) or in a combination of various techniques (complex alternation).

The realization of systematic alternation by means of consonant gradation is the most widely applied technique. In consonant gradation, two grades are distinguished, a strong grade and a weak grade. These correlate with specific syllable types. The strong grade correlates with an open syllable, the weak grade with a closed syllable. Open syllables are those ending in a vowel, closed syllables end in a consonant. The sound changes which occur when consonant gradation operates may be quantitative (e.g. pp: p, piippu 'pipe/nominative': piipun 'pipe/ genitive') and qualitative (e.g. k: Ø, joki 'river/nominative': joen 'river/genitive').

The described alternations of the word stem are a heritage from the times when Indo-European languages exerted a strong influence on the Baltic-Fennic languages in their formative period.

\section{Scenarios of a dominance of non-Indo-Euro- pean elements over Indo-European elements}

Indo-Europeanization may articulate itself in certain ways, so that despite the massive impact of Indo-European culture, life-style and language, there is no shift to a predominance of Indo-European constituents in a local culture and language. The scenario of Indo-European and Uralic in contact in the Baltic region illustrates such proportions of fusion.

In the course of their advance into central Europe, the Indo-Europeans who had left their homeland as pastoralists shifted to an agrarian subsistence. Agriculture, as practised by the ancestors of the Baltic tribes, reached the southern part of the Baltic region by about $1800 \mathrm{BC}$. The emergence of the Balto-Fennic branch of Fenno-Ugrian (as a major subdivision of Uralic) falls within the span of time when the Fennic population in the Baltic region experienced their transition to sedentism and plant cultivation $(c$. 1500-1000 BC).

It is significant that, in the Baltic region, an exceptionally prolonged phase of transition can be observed, lasting some 700 years. Among the distinct features of this phase is "the existence of mixed huntingfarming groups, characterized by an extended sub- 
stitution phase..." (Zvelebil 1996.328-329). At an early date, the zone of mixed hunting-farming groups was located in an area stretching from western Prussia and northern Poland to eastern Prussia and southern Lithuania. From there it gradually shifted in a northeastern direction.

Concluding from the archaeological record and, particularly, judging from the existence of mixed hunting-farming groups, contacts between the southern (Baltic) agriculturalists and the northern (Fennic) foragers were friendly. The foragers had a vast hinterland for hunting activities where they could withdraw with the spread of sedentism and the agrarian life-style into territories which were formerly hunting-grounds. In addition to this factor of ample space, the two groups engaged in mutual trade (Map 4).

Among the commodities of the north, one was particularly preferred by men in the south, namely women. These were mostly obtained via bride purchase. In a cross-cultural comparison of contacts between agriculturalists and foragers, it can be stated that the farming culture is viewed by both parties as more prestigious. The higher prestige of the farming culture also created images of a more advanced society among foragers, in a way that the communities of the south became more and more attractive for women of the north who had a chance to marry into the prestigious society (Haarmann 2003c.98-100).

Against the background of unilaterally directed prestige relations, it is not surprising to observe that the lively social intermingling between farmers and foragers resulted in a unilaterally directed innovation of the social terminology among the speakers of Fennic languages. An indicator of this is the broad layer of loanwords of Baltic origin in two sensitive sections of the basic vocabulary of Fennic languages, in kinship terminology and, in the terminology for body parts (Tab. 7). Since prestige values were asso-

\section{(a) TERMINOLOGY OF KINSHIP AND SOCIAL RELATIONS}

Finnish lapsi 'child', tyttö 'girl', nainen 'woman', häät 'wedding', morsian 'bride', sulhanen 'bridegroom', lanko 'wife's brother; husband's brother', nuode 'sister's husband', tytär 'daughter', veli 'brother', sisar 'sister', etc.

\section{(b) TERMINOLOGY OF BODY PARTS AND BODILY FUNCTIONS}

Finnish raaja 'extremity', limb', kaula 'neck', leuka 'jaw', hammas 'tooth', ranne 'wrist', karva 'hair (of the body)', napa 'navel', koipi 'upper leg (of animals)', reisi' 'thigh', perna 'spleen', hiki 'sweat', hilse 'scurf', virtsa 'urine'.

Tab. 7. Lexical borrowings of Baltic origin in Finnish (after Haarmann 2003c.98-100); a) Terminology of kinship and social relations; b) Terminology of body parts and bodily functions.

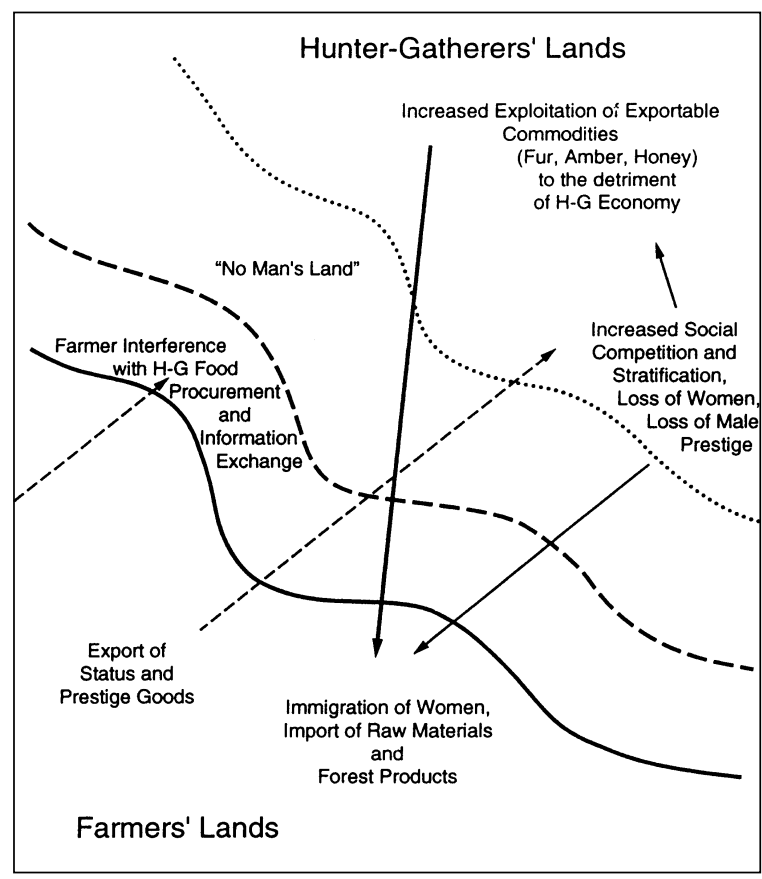

Map 4. Trade relations and socio-economic competition in the Baltic convergence zone (after Zveleciated with the culture of the south, conceptualizations of prestige extended to also include the language of the south that was involved in the contact (i.e., Baltic).

\section{Outlook}

The stage of transition from a hunter-gatherer ecoy to pastoralism in the steppe zone can as yet ments.

At present, it is not possible to distinguish different layers of the Proto-Indo-European vocabulary according to absolute chronology (i.e., pastoralist terminology vs. agrarian vocabulary). In this domain, only statements about relative chronology can be made, along the lines that pastoralist terminology must be older than the younger - and more scarce agricultural vocabulary. The exclusive application of the methods of historical linguistics which are available at present (i.e. lexico-statistical dating) does not produce sati- 
sfactory results for the pinpointing of the date of the dissolution of the Proto-Indo-European complex and its dispersal into regional cultures and languages. Estimates range from $c .4500 \mathrm{BC}$ to $c .3000 \mathrm{BC}$.

It is essential to correlate insights about the relative chronology of transitions and events during the formative period of the Indo-European complex and of the fusion processes induced by contacts with non-
Indo-European populations to an absolute time-frame. This task calls for interdisciplinary cooperation, exploring the chronological depth of the prehistory of the steppe zone in an orchestrated fashion to refine dating methods in archaeology (archaeobotany), human genetics (genomic profiles of ancient populations and their distribution), anthropology (human ecology), studies of cultural and linguistic fusion processes, and historical linguistics.

\section{$\therefore$}

\section{REFERENCES}

ABONDOLO D. (ed.). 1998. The Uralic languages. Routledge. London \& New York.

AKURGAL E. 2001. The Hattian and Hittite Civilizations. Publications of the Ministry of Culture. Ankara.

BAILEY D. W. 2000. Balkan Prehistory: Exclusion, Incorporation and Identity. Routledge, London \& New York.

BARBER E. W. 1991. Prehistoric Textiles. The Development of Cloth in the Neolithic and Bronze Ages. Princeton University Press. Princeton.

BEEKES R. S. P. 1995. Comparative Indo-European linguistics. An introduction. John Benjamins. Amsterdam \& Philadelphia.

BELL-FIALKOFF A. (ed.). 2000. The role of migration in the history of the Eurasian steppe. Sedentary civilization vs. "barbarian" and nomad. Macmillan. London.

BREYER G. 1993. Etruskisches Sprachgut im Lateinischen unter Ausschluss des spezifisch onomastischen Bereiches. Peeters. Leuven.

BUDJA M. 2001. The transition to farming in Southeast Europe: perspectives from pottery. In M. Budja (ed.), $8^{\text {th }}$ Neolithic Studies. Documenta Praehistorica 28: 27-47.

2005. The process of Neolithisation in South-eastern Europe: from ceramic female figurines and cereal grains to entoptics and human nuclear DNA polymorphic markers. In M. Budja (ed.), 12th Neolithic Studies. Documenta Praehistorica 32: 53-72.

CARPELAN C., PARPOLA A. 2001. Emergence, Contacts and Dispersal of Proto-Indo-European, Proto-Uralic and Proto-Aryan in Archaeological Perspective. In C. Carpelan, A. Parpola, P. Koskikallio (eds.), Early contacts between Uralic and Indo-European: Linguistic and archaeological considerations, Suomalais-Ugrilainen Seura. Helsinki: 55-150.
CAVALLI-SFORZA L. L. 1996. The spread of agriculture and nomadic pastoralism: insights from genetics, linguistics and archaeology. In D. R. Harris (ed.), The Origins and Spread of Agriculture and Pastoralism in Eurasia. UCL Press, London: 51-69.

2000. Genes, peoples, and languages. North Point Press. New York.

CAVALLI-SFORZA L. L., MENOZZI P., PIAZZA A. 1994. The History and Geography of Human Genes. Princeton University Press, Princeton. New Jersey.

ÇILINGIROGLU C.. 2005. The concept of "Neolithic package": considering its meaning and applicability. In M. Budja (ed.), 12 th Neolithic Studies. Documenta Praehistorica 32: 1-13.

DERGACHEV V. 2002. Two studies in defence of the migration concept. In K. Boyle, C. Renfrew, M. Levine (eds.), Ancient interactions: east and west in Eurasia. McDonald Institute for Archaeological Research, Cambridge: 93-112.

2005. 0 skipetrakh. Etjudy v zashchitu migratsionnoi kontseptsii M. Gimbutas. Revista arheologica, serie noua, vol. 1. Monografie, Chisinau.

DI GIACOMO F. et al. 2004. Y chromosomal haplogroup J as a signature of the post-Neolithic colonization of Europe. Human Genetics 115: 357-371.

DOLUKHANOV P. M. 2002. Alternative revolutions: hunter-gatherers, farmers and stock-breeders in the northwestern Pontic area. In K. Boyle, C. Renfrew, M. Levine (eds.), Ancient interactions: east and west in Eurasia. McDonald Institute for Archaeological Research, Cambridge: $13-24$.

DUHOUX Y. 1998. Pre-Hellenic Language(s) of Crete. Journal of Indo-European Studies 26: 1-39. 
FUNK D. A., SILLANPÄÄ L. (eds.) 1999. The small indigenous nations of northern Russia. A guide for researchers. Social Science Research Unit, Publication No. 29. Åbo Akademi University, Vaasa.

GAMKRELIDZE T. V. and IVANOV V. V. 1995. Indo-European and the Indo-Europeans, vol. I. Mouton de Gruyter. Berlin \& New York.

GIMBUTAS M. 1974. The gods and goddesses of old Europe, 7000-3500 B.C. myths, legends, cult images. Thames \& Hudson. London: [2nd ed. 1982 as The goddesses and gods of Old Europe, 6500-3500 B.C.].

1991. The civilization of the goddess: The world of old Europe. Harper, San Francisco.

1992. Die Ethnogenese der europäischen Indogermanen. Institut für Sprachwissenschaft der Universität Innsbruck. Innsbruck.

HAARMANN H. 1986. Language in ethnicity. A view of basic ecological relations. Mouton de Gruyter. Berlin \& New York.

1995. Early civilization and literacy in Europe. An inquiry into cultural continuity in the Mediterranean world. Mouton de Gruyter, Berlin \& New York.

1996. Aspects of early Indo-European contacts with neighboring cultures. Indogermanische Forschungen 101: $1-14$.

1998a. Basque ethnogenesis, acculturation, and the role of language contacts. In Fontes Lingvae Vasconvm. Studia et documenta 77: 25-42.

1998b. On the problem of primary and secondary diffusion of Indo-Europeans and their languages. Journal of Indo-European Studies 26: 391-419.

2000. Russische Identität und geopolitische Realitäten im Spiegel der postsowjetischen Sprachkontakte. In L. N. Zybatow (ed.), Sprachwandel in der Slavia. Die slavischen Sprachen an der Schwelle zum 21. Jahrhundert - Ein internationales Handbuch, Teil 2. Peter Lang, Frankfurt, Berlin \& New York: 725-749.

2002. Lexikon der untergegangenen Sprachen. C. H. Beck, Munich (2nd ed. 2004).

2003a. Latein. In Variationstypologie. Roelcke T. (ed.), Walter de Gruyter, Berlin \& New York: 325-358.

2003b. Finnish. In Variationstypologie, Roelcke T. (ed.), Walter de Gruyter, Berlin \& New York: 866904. 2003c. Language, economy and prestige in the context of Baltic-Fennic contacts. Studia Indogermanica Lodziensia 5: 87-102.

2006a. Weltgeschichte der Sprachen. Von der Frühzeit des Menschen bis zur Gegenwart. C. H. Beck, Munich.

2006b. On the fabric of Old World civilizations: Human response to the Black Sea flood and subsequent climatic change. Journal of Archaeomythology 2: 2764 .

2007. Foundations of culture. Knowledge-construction, belief systems and worldview in their dynamic interplay. Frankfurt, Berlin \& New York: Peter Lang.

HAARMANN H., HOLMAN E. 1997. Acculturation and communicative mobility among former Soviet nationalities. Annual Review of Applied Linguistics 17: 113-137.

HAJDÚ P., DOMOKOS P. 1987. Die uralischen Sprachen und Literaturen. Buske. Hamburg.

HELSKOG K. 1988. Helleristningene i Alta. Spor etter ritualer og dagligliv i Finnmarks forhistorie. Alta Museum. Alta.

HOFMANN J. B. 1966. Etymologisches Wörterbuch des Griechischen. Wissenschaftliche Buchgesellschaft. Darmstadt.

KATIČIĆ R. 1976. Ancient Languages of the Balkans, vol. 1, Mouton. The Hague \& Paris.

KOIVULEHTO J. 2001. The earliest contacts between IndoEuropean and Uralic speakers in the light of lexical loans. In C. Carpelan, A. Parpola, P. Koskikallio (eds.), Early contacts between Uralic and Indo-European: Linguistic and archaeological considerations. Suomalais-Ugrilainen Seura, Helsinki: 235-263.

LEVINE M., RASSAMAKIN R., KISLENKO A., TATARINTSEVA N. (eds.) 1999. Late prehistoric exploitation of the Eurasian steppe. McDonald Institute for Archaeological Research. Cambridge.

MAKKAY J. 2001. The Earliest Proto-Indo-European-ProtoUralic Contacts: An Upper Palaeolithic model. In C. Carpelan, A. Parpola, P. Koskikallio (eds.), Early contacts between Uralic and Indo-European: Linguistic and archaeological considerations. Suomalais-Ugrilainen Seura, Helsinki: 319-343.

MALLORY J. P. 1989. In Search of the Indo-Europeans: Language, archaeology and myth. Thames and Hudson. London. 
1997. Indo-European homeland. In J. P. Mallory, D. Q. Adams (eds.), Encyclopedia of Indo-European culture. Fitzroy Dearborn Publishers, London \& Chicago: 290299.

MALLORY J. P., ADAMS D. Q. (eds.) 1997. Encyclopedia of Indo-European culture. Fitzroy Dearborn Publishers, London \& Chicago.

MARLER J. 2005. The beginnings of patriarchy in Europe: Reflections on the Kurgan theory of Marija Gimbutas. In C. Biaggi (ed.), The rule of Mars. Readings on the origins, history and impact of patriarchy, Knowledge, Ideas \& Trends, Manchester: 53-75.

MENGES K. H. 1995. The Turkic languages and peoples. An introduction to Turkic Studies. Harrassowitz. Wiesbaden (2nd ed.).

NIAMIR M. 1995. Indigenous systems of natural resource management among pastoralists of arid and semi-arid Africa. In D. M. Warren, L. J. Slikkerveer, D. Brokensha (eds.), The cultural dimension of development. Indigenous knowledge systems. Intermediate Technology Publications. London.

OTKUPSHCHIKOV Y. V. 1973. Balkano-maloaziyskie toponomicheskie izoglossy. In Balkanskoe Yazykoznanie. Moscow: 5-29.

PARPOLA A. 1999. Varhaisten indoeurooppalaiskontaktien ajoitus ja paikannus kiellelisen ja arkeologisen aineiston perusteella. In P. Fogelberg (ed.), Pohjan poluilla. Suomalaisten juuret nykytutkimuksen mukaan. Suomen Tiedeseura. Helsinki: 180-206.

RENFREW C. 1987. Archaeology \& Language. The Puzzle of Indo-European Origins. Jonathan Cape. London.

1999. Time depth, Convergence Theory, and Innovation in Proto-Indo-European: 'Old Europe' as a PIE Linguistic Area. Journal of Indo-European Studies 27: 258-293.

2002a. Pastoralism and interaction: Some introductory questions. In K. Boyle, C. Renfrew, M. Levine (eds.), Ancient interactions: east and west in Eurasia. McDonald Institute for Archaeological Research, Cambridge: 1-10. 2002b. "The emerging synthesis": the archaeogenetics of farming/language dispersals and other spread zones. In P. Bellwood, C. Renfrew (eds.), Examining the farming/language dispersal hypothesis. McDonald Institute for Archaeological Research, Cambridge: 3-16.

RYAN W., PITMAN W. 1998. Noah's Flood. The new scientific discoveries about the event that changed history. Simon and Schuster. New York.

SEMINO 0. et al. 2004. Origin, diffusion, and differentiation of Y-chromosome haplogroups $\mathrm{E}$ and J: Inferences on the Neolithization of Europe and later migratory events in the Mediterranean area. American Journal of Human Genetics 74: 1023-1034.

SHISHLINA N. I. 1997. Zametki o kharaktere skotovodcheskogo khozyaistva v sovremennoi republike Kalmykiia. In P. M. Kozhin (ed.), Step' $i$ Kavkaz (kul'turnye traditsii). Trudy gosudarstvennogo istoricheskogo muzeia 97: 106-109.

2004. North-west Caspian sea steppe: Environment and migration crossroads of pastoral culture population during the third millennium BC. In E. M. Scott et al. (eds.), Impact of the environment on human migration in Eurasia. Kluwer Academic Publishers, Amsterdam: 91-106.

STRUNK K. 2003. Vorgriechisch/'Pelasgisch': Neue Erwägungen zu einer älteren Substrathypothese. In A. Bammesberger and T. Vennemann (eds.), Languages in prehistoric Europe. Winter, Heidelberg (2nd ed.): 85-98.

SUHONEN S. (ed.). 1995. Itämerensuomalainen kulttuurialue/The Fenno-Baltic cultural area. Suomalais-Ugrilainen Seura. Helsinki.

VIDEYKO M. Yu. 2003. Tripil's'ka tsivilizatsiia. Akademperiodika Kiev (2nd ed.).

WHITTLE A. 1996. Europe in the Neolithic: The Creation of New Worlds, Cambridge University Press. Cambridge.

ZVELEBIL M. 1996. The agricultural frontier and the transition to farming in the circum-Baltic region. In D. R. Harris (ed.), The origins and spread of agriculture and pastoralism in Eurasia, UCL Press, London: 323-345. 